\title{
MILLENNIAL LECTURERS' ATTITUDES IN INCORPORATING THE ONLINE APPLICATION IN THE EFL CLASSROOM
}

\author{
Angela Bayu Pertama Sari ${ }^{1}$, Catharina Brameswari ${ }^{2}$, Haya Haratikka ${ }^{3}$ \\ ${ }^{1}$ Universitas Bina Sarana Informatika \\ ${ }^{2}$ Universitas Sanata Dharma \\ ${ }^{3}$ Sekolah Tinggi Ilmu Ekonomi Bina Karya \\ ${ }^{1}$ angela.abp@bsi.ac.id, ${ }^{2}$ catharinabrameswari@usd.ac.id, ${ }^{3}$ hayaharatikka@gmail.com
}

\begin{abstract}
Millennial lecturers are considered to be proficient in teaching by making use of the technology in their classrooms. Nine millennial lecturers were involved in this study. It was carried out as qualitative research. The data collection technique was open-ended questionnaires then analyzed through thematic analysis. Three research questions were aimed to be examined. The first one was the investigation on the variety of the online applications used in the EFL classrooms; the second one was questioning about the lecturers' attitudes in getting the benefits of online application, and the third one was observing the lecturers' attitudes in overcoming the limitations that they found in incorporating the online application in the EFL classroom. The results showed that seventeen types of the online mobile application that were used by the nine millennial lecturers in this study. The millennial lecturers took advantage of the online applications by establishing communication, encouraging students' self-study, improving the assessment, motivating the students, and improving the teaching instruction. Other result showed that they overcame the limitations of online mobile applications by giving more information and giving assignment to solve the learning management issues and also adjusting the learning when tools issues occur.
\end{abstract}

Keywords: Millennial, Lecturer, Online Application, EFL

\section{INTRODUCTION}

Learning English as a foreign language holds a significant role in education as it is seen in many non-English spoken countries. Indonesia is one of the non-English spoken country where English becomes a compulsory course in Indonesian universities or colleges. Not only for the English major but the non-English major students are also required to take an English course as one of the requirements to graduate. The students face some obstacles in learning English such as the limited language instruction in class (Diaz-Vera, 2012). Since English is the course that needs more time to practice, on some occasions, the course hour is not enough to accommodate the learning activities in the classroom. Moreover, Phillips (2019) states other issues that the non-English major students generally are not interested in English study.

Accordingly, the English learning system needs a media that can expand the English language instruction and provide enjoyable language learning. Regarding this matter, smartphones are capable of providing services to support language learners with ease, flexibility and fun atmosphere (Byrne \& Diem, 2014). One of the popular positive features of smartphones is their ability to foster language learning through mobile applications (Mindog, 2016). Also, El Hariry (2015) mentions that many researchers agree that various types of applications and different learning and teaching techniques could be employed to gain a better quality of education. 
Some prior studies provide pieces of evidence on the significant role of mobile phone applications in supporting English learning. In her study that was conducted towards four Japanese university students, Mindog (2016) found out that the application helps the students with not only the four language skills (listening, reading, writing and speaking) but also grammar, vocabulary, and spelling. Another study was conducted by Chung, Chen, \& Kuo (2015). They collected the data by using questionnaires that were administered to eighty-four EFL college students. The result showed that Internet applications dramatically enhance the convenience of English foreign language learning in terms of ease of use, self-efficacy, usefulness, and compatibility. Phillips (2019) in her study adds that the students in the Japanese university felt that the range of popular English learning applications in their smartphones brought usefulness and, enjoyment. Moreover, Hosain (2018) conducted a study by distributing questionnaires to 150 non-English major students in Bangladesh. The result presented the high interest of the students in making the best use of the English learning applications. However, some limitations were still found such as the teachers were still following the traditional system and there was still a small number of the teaching process that incorporates mobile technology in its process.

Following the prior study, it is vividly observed that there is still limited study that investigates the incorporation of mobile application in the English teaching and learning process that is conducted by the millennial lecturers. Millennial lecturers are the potential figure in education nowadays by having similar characteristics with the students whom they teach. Millennial lecturers are those who were born in the year 1979 through 2002 (Erickson, 2008). Jerome, Scales, Whithem, \& Quain (2014) explain that millennial generation is also called as digital generation since they constantly interact with the technology in everyday life. Furthermore, Erickson (2008) stresses that the millennial generation very experiences with the internet as the source of information.

Thus, this study attempts to dig out the millennial lecturers' attitudes in incorporating online applications in the teaching and learning process. Three research questions are formulated in this study; it is mentioned as follows:

What are the online applications that are used the the millennial lecturers in the teaching process?

How do the millennial lecturers get the benefits from the online applications implementation in the teaching process?

How do the millennial lecturers cope with the limitations in the implementation of online applications in the teaching process?

\section{METHOD}

This study was conducted in the form of qualitative research. Qualitative research was a set of approaches with the purpose to serve a description and interpretation of the particular research topic (Smith, Bekker, \& Cheater, 2011). Unlike quantitative research, qualitative research used small samples (Rejeki \& Azizah, 2019). The research participants were nine English Foreign Language lecturers from six different universities. One of them teaches in public university and eight of them teach in the private universities. Those participants consisted of 4 male lecturers and 5 female lecturers. They were born in 1980-1991 who belong to the millennial generation (Erickson, 2008). Thus, they are categorized as the millennial lecturers in the EFL classes. 
Table 1. Description of the nine millennial lecturers

\begin{tabular}{ccc}
\hline Name & Gender & Year of born \\
\hline Lecturer 1 & Male & 1990 \\
Lecturer 2 & Female & 1991 \\
Lecturer 3 & Male & 1989 \\
Lecturer 4 & Female & 1990 \\
Lecturer 5 & Female & 1988 \\
Lecturer 6 & Male & 1980 \\
Lecturer 7 & Male & 1986 \\
Lecturer 8 & Female & 1986 \\
Lecturer 9 & Female & 1989 \\
\hline
\end{tabular}

The data collecting techniques employed an open-ended questionnaire through the emailbased system. The data were in the form of phrases, sentences, and paragraphs. The data analyzing technique used thematic analysis. Thematic analysis is categorized as one of the qualitative descriptive design (Vaismoradi, Jones, Turunen, \& Snelgrove, 2016). The importance of theme in the research was highlighted by Braun \& Clarke (2006) who stated that a theme portrays a significant element of the data that had a relation with the formulated research questions. A theme also provides patterned responses or a meaningful data set.

The thematic data analysis in this study was conducted based on the data analysis phases that were proposed by (Nowell, Norris, White, \& Moules, 2017):

1. Making the researcher familiar with the data

2. Generating initial codes

3. Discovering the themes

4. Reviewing and checking the themes

5. Defining and naming themes

6. Writing the report

\section{RESULTS AND DISCUSSION}

\section{Results}

The variety of online applications that were used by the millennial lecturers

The results showed seventeen online applications were used by the millennial lecturers in their teaching process. Those applications were classified into seven categories that were described in table 2:

Table 2. Categorization of the online applications used by the millennial lecturers

\begin{tabular}{ccc}
\hline Categories & $\begin{array}{c}\text { Names of online } \\
\text { applications }\end{array}$ & Frequency of usage \\
\hline Discussion forum & WhatsApp, Mentimeter & 1 \\
Classroom learning & Google Classroom, & 2 \\
management & Canvas & 2 \\
Self Study & Elsa, Hello English & 3 \\
Quizlet, Evernote, & \\
Real-time exercise & $\begin{array}{c}\text { Mindomo, Storyboard that } \\
\text { Quiziz, Kahoot, Google } \\
\text { Forms }\end{array}$ & 4 \\
Video & TED, Edpuzzle, YouTube & 2 \\
Music & Spotify & 1 \\
\hline
\end{tabular}


According to table 2, there were seven categories of online applications based on their usage. The first one was for the discussion forum. Lecturer 5 stated that "seeing that every student has a smartphone inspire me why not creating supplementary materials or assessment through apps: WhatsApp and Mentimeter". WhatsApp is a chatroom-based online application that enables the users to share messages in the form of text, video, pictures, sound and location. Mentimeter is an online app that is usually used for polling tools in the form of voting or openended responses. It is in line with Mobinizad (2018) who stated that lecturers could make use of online applications for live polling tools and chatting tools or another online discussion forum in the classroom. This application could encourage students to be more active in-class participation.

In the next finding, lecturer 1 and lecturer 8 said that they used google classroom and canvas for managing their classroom activity. Those two applications enabled the lecturers to expand their classroom activity in the online platform. It is supported by Chergui, Begdouri, \& GrouxLeclet (2017) who stated that the online application for classroom management system was the extension of e-learning when the students accessed the learning materials in the app and made interaction through it.

Another result showed that lecturer 2 and lecturer 7 explained that they incorporated the online applications for introducing the students to do self-study. Elsa is an application that enables users to practice speaking, listening, and pronunciation by themselves. Hello English is also an online self-study app that focuses on grammar and writing practices. Application for self-study brought positive impacts for the learners since it provided a unique scaffolding method that was adjusted with the individual language performance (Squire \& Dikkers, 2012).

In the following research finding, lecturer 1, 4 and 9 reported that they implemented the learning activities by using Quizlet, Evernote, Mindomo and Storyboard that. Quizlet is an application for creating a flip card that is significant for vocabulary builder activity. Evernote is an online writing composer that is suitable for writing practice. Mindomo is a tool for transforming ideas into mind map. Storyboard-that is an online tool for making stories with beautiful pictures, as a comic. Those applications enabled both lectures and students to create English content that was impactful for the process of learning. Those content creator applications made the students and lecturers easier in writing, making video captures, recording audio and video and even making online eBooks just by drag and drop features learning (Chergui et al., 2017).

Lecturer 1, 5, 6 and 8 informed that they used Quiziz, Kahoot and Google forms as the assessment tools for their teaching. Quiziz and Kahoot are similar applications that are used for a real-time quiz with fun features. Google forms functions as an online quiz with the automated assessment. Chergui et al. (2017) study showed a similar result that the online application might work as students' knowledge evaluation through assessment that could be more appealing on mobile phone through the touch screen device.

The use of the application for accessing the video was expressed in the responses of lecturer 5 and lecturer 8. Some applications such as Edpuzzle, TED and YouTube were used by those lecturers. Edpuzzle is an online application that allows users to create exercises through the video. TED and YouTube are famous online video platforms that serve users with millions of videos. The integration of technology, particularly the video into the learning satisfied the students in both visuals and auditory senses Solanki et al. as cited in (Yordming, 2017).It was also illustrated in the last finding of this category that there was one lecturer who made use of an audio-based online application called as Spotify to support his teaching. The development 
of teaching materials with online audio created upliftment of teaching style that became more favourable for the learners Solanki et al. as cited in Yordming (2017).

\section{Millennial lecturers' attitudes in getting the benefits of incorporating the online applications in their teaching process}

To address the second research question, asking how the millennial lecturers get the benefits from the online application implementation in the teaching process, the researchers extracted the data from the open-ended questionnaires as it was identified in table 3 . The letter " $L$ " meant lecturer.

Table 3. Categorization of lecturers' attitudes in getting the benefits of incorporating online application to their teaching process

\begin{tabular}{|c|c|}
\hline Categories & Millennial lecturers' attitudes \\
\hline $\begin{array}{l}\text { Establishing } \\
\text { communication }\end{array}$ & I use g classroom as the media for communication (L1). \\
\hline $\begin{array}{c}\text { Encouraging students' } \\
\text { self-study }\end{array}$ & $\begin{array}{l}\text { I help my students to be more independent at least to } \\
\text { recheck and relearn the learning materials in the } \\
\text { classroom (L1). } \\
\text { I introduce the students with the self-study materials } \\
\text { (L2)(L7) } \\
\text { I encourage the students to access the LMS and the video } \\
\text { tutorial outside the classrooms in their convenient time } \\
\text { and place (L3)(L8) } \\
\text { I tell them to play game-based application for self-study } \\
\text { (L4) }\end{array}$ \\
\hline Improving the assessment & $\begin{array}{l}\text { I usually ask students to upload their task (audio/video/ } \\
\text { images/ mind-mapping) on the online application with a } \\
\text { more comfortable way (L1) (LA)(L6)(L9) } \\
\text { I give them feedback and comment on the file they } \\
\text { uploaded. (L1)(L4) } \\
\text { I use those applications to make my assessment more } \\
\text { efficient (L1)(L8) } \\
\text { I ask my students to work on online tasks and quiz (L1, } \\
\text { L2) } \\
\text { I make the assignment to be paperless (L9) }\end{array}$ \\
\hline Motivating the students & $\begin{array}{l}\text { I use those applications and they make students' mood } \\
\text { better (L1) } \\
\text { I use it for icebreaking in the class (L1) } \\
\text { I make my students more motivated in writing with the } \\
\text { online applications (L4) } \\
\text { I employ that application to make my students more } \\
\text { motivated and challenged (L5) } \\
\text { I create more engaging activity among the students with } \\
\text { that application (L8) }\end{array}$ \\
\hline $\begin{array}{l}\text { Improving the teaching } \\
\text { instruction in the } \\
\text { classroom }\end{array}$ & $\begin{array}{l}\text { I use quizlet especially for giving students some } \\
\text { vocabulary they are going to use in the next meeting } \\
\text { (L1). }\end{array}$ \\
\hline
\end{tabular}


I use the application as the supplementary class and teaching assistant equipment $(L 2, L 6)$

I differentiate instructions that can help to serve

students with different learning backgrounds and styles

by using that application (L3)

I use it for brainstorming because it has interesting

visual interface and timer (L5)

I implement it in class for additional interactive online

activity (L6)

The research result in table 3 showed that there were six categories of millennial lecturers' attitudes in getting the benefits from incorporating the online application in their teaching process. The first category was the lecturer's attitude in establishing discussion forum. Lecturer 1 stated that "I use g classroom as the media for communication". J.S. Artal-Sevil as cited in Chergui (2017) supported the research finding by stating that one of the mobile application usages in a higher education learning process was for communication tools. By utilizing the online application, the lecturers might interact with their students to manage the learning outside the classroom. This was a free and convenient way for the lecturers to broaden the communication outside the classroom and to be connected with the students more.

Some mobile applications allowed the students to do self-study. The data revealed that the lecturers supported the students to do self-study as it appeared in their responses. In the traditional method, lecturers used homework as a media to encourage the students to do selfstudy. Azizah (2018) stated that every teacher had a distinctive way of assigning homework for their students. In this study, the millennial lecturers had developed the way they pushed their students to study independently through some activities. Lecturer 1 stated that "I help my students to be more independent at least to recheck and relearn the learning materials in the classroom". This attitude showed the lecturer's motive to encourage the students to study the learning material further by themselves. Then, lecturer 2 and lecturer 7 affirmed that the lecturers suggested the learning materials that could be learned independently by themselves: "I introduce the students with the self-study materials". Furthermore, lecturer 3 and lecturer 8 also did similar attitudes as it was stated in their responses "I encourage the students to access the LMS and the video tutorial outside the classrooms in their convenient time and place”. Steel (2012) as cited in Mobinizad (2018) assured that smartphones with rich features of mobile applications fitted the students' busy life. Then, Cavus \& Ibrahim (2008) added that the students enjoyed practical and flexible learning method that they found in the mobile applications. Accordingly, the students could profitably make use of mobile applications in smartphones in their spare time to learn the English materials autonomously. Also, lecturer 4 specified the types of learning activities for the students' self-study that was by using the game-based application. That application was not solely about games, but it established English learning experiences for the students. This finding was also highlighted by several studies. (Boja \& Batagan, 2009) contended that integrating games into learning transformed the traditional learning atmosphere into a creative situation that likely made the students felt less boredom. Besides, the mobile applications in the smartphone created engaging and fun learning activities that fitted the students' social life (Bray \& Iswanti, 2013).

The next finding showed evidence about the lecturers' attitudes with their effort to improve the assessment system. Lecturer 1, 4, 6 and 9 declared that they usually asked the students to submit their assignment in the form of audio, video, images and mind-mapping through the online applications. It indicated positive responses from the students since this kind of assignment submission system became their favourable method due to the flexibility. Moreover, the 
lecturers found the mobile applications useful for accommodating the variety of students' assignments. This result was confirmed by Mobinizad (2018) study that presented the positive feature of online applications for assessment. Those online applications could be storage for assignments with various types of files such as video, audio, images, text, and mind-mapping. Additionally, lecturer 1 and lecturer 8 mentioned that they significantly got the benefits of employing the online mobile applications since it cut down their work on the students' assessment and it became more efficient in scoring. Lecturer 1 and lecturer 2 also added that they created some activities for the students to practice on online tasks and online quizzes. In this matter, online applications served as knowledge evaluation tools to gauge the leaners level of understanding (Chergui et al., 2017). The feature of online application as the assessment for learning was perceived to be an advantageous tool for the lecturers because they could provide the students with not only scores but also feedback and comments (lecturer 1 and lecturer 4 ). At last, the lecturer 9 profitably perceived that the paperless assignment through the online application submission suited to the students' learning preferences. It was confirmed by Hidayati \& Endayani (2019) that the students preferred technological tools rather than the printed one for the learning.

The lecturers' attitudes in motivating the students through mobile applications were also clearly seen in the research results. Lecturer 1 said, "I use those applications and they make students' mood better". She also added that she used it for icebreaking. Lecturer 4 enriched the findings by stating "I make my students more motivated in writing with the online applications". Furthermore, lecturer 5 and lecturer 8 reported their action in incorporating the online mobile applications that created motivating, challenging and engaging activities for learning. Some studies also came into agreement with the research findings. Gamlo (2019) emphasized that using mobile game-based language learning brought a significant impact on the learners' motivation. Besides, Kacetl \& Klímová (2019) argued that the students who used mobile technologies seemed to be more motivated to learn both inside and outside the classroom.

The last finding for this category was the lecturers' attitudes in improving the teaching instructions through mobile applications. Lecturer 2 and lecturer 6 explained that they used the applications for their class supplementary materials and also for their teaching assistant equipment. Then, lecturer 1 and lecturer 6 specified that they used the mobile applications for supporting their learning materials with vocabulary exposures and visual media to brainstorm their students before learning. Solakin et al. as cited inYordming (2017) strengthened this finding by stating that teaching English in this new era required a set of students' favorable media that featured videos, images and animation to make the learning more playful. Likewise, lecturer 6 emphasized that she implemented the mobile application for an online interactive activity. It is in line with Zhang (2017) who proposed that mobile application might adapt the teaching content that came into improvement. At last, lecturer 3 asserted that he differentiated the instructions in the classroom by incorporating the online mobile applications in the learning process. Some researches were in line with this finding. Eppard, Nasser, \& Reddy (2016) affirmed that in the $21^{\text {st }}$ century English classroom, the lecturers had to integrate mobile applications in their teaching. Moreover, Chergui et al. suggested that lecturers should redesign and make use of new mobile applications based on the students' specific learning needs and style. From the analysis and description in this category, the researchers wrapped up that millennial lecturers' attitudes in getting benefits from the online applications for their teaching were so various. It indicated that the millennial lecturers were so literate and skillful in using the technology for improving their teaching quality. 


\section{Millennial lecturers' attitudes in coping with the obstacles that they face on incorporating the online application in their teaching process}

To answer the third research question, the researchers analyzed the data obtained from the openended questionnaires. The result elaborated on the lecturers' attitudes in coping with the obstacles that they found in incorporating the online applications in their teaching process.

Table 4. Categorization of lecturers' attitudes in coping with the limitations in the implementation of online applications in the teaching process

\begin{tabular}{cl}
\hline Categories & \multicolumn{1}{c}{ Millennial lecturers' attitudes } \\
\hline $\begin{array}{c}\text { Giving more information } \\
\text { and monitored assignment } \\
\text { to overcome the learning } \\
\text { management issues }\end{array}$ & $\begin{array}{l}\text { The students are still accustomed to the old culture } \\
\text { (teacher-centred) so I encourage them to shift their } \\
\text { tradional thinking }(L 1, L 9)\end{array}$ \\
& $\begin{array}{l}\text { For some applications, the lecturers have no control } \\
\text { over the learning activities so I asked them to retell } \\
\text { report what they have learned from the learning } \\
\text { activities }(L 2) .\end{array}$ \\
Adjusted the learning \\
when tools issues occur \\
$\begin{array}{l}\text { Students have no internet connection so I encourage } \\
\text { them to use campus Wi-fi or ask them to share their data } \\
\text { plan with theirfriends }(L 3, \text { L4, L5, L6, L8) }\end{array}$ \\
$\begin{array}{l}\text { Some applications are not completely free so I tried to } \\
\text { modify the learning activities limited to the features of } \\
\text { the free online applications }(L 7)\end{array}$
\end{tabular}

Data in table 4 portrayed that two main issues were encountered by the millennial lecturers in implementing the online applications in their teaching process. Lecturer 1 and lecturer 9 asserted that they attempted to shift the traditional thinking of being accustomed to the teachercentered system to the student-centered system by incorporating the online mobile applications. Moreover, the lack of lecturers' control in the learning process was indicated as one of the obstacles in using the online applications for English learning, particularly for learning outside the classroom (lecturer 2). This problem was also found in the study conducted by Zhang (2017) which reported that the students found it confusing to select the learning materials outside the classroom without the lecturers' assistance. Thus, lecturer 2 made action by tracking the students' learning progress by giving an assignment in the form of retelling or reporting what things that they had learned from their activities with the online applications.

The main limitation in the implementation of online applications in the millennial lecturers' teaching process was the technical problem. It is similar to the research finding of Kacetl \& Klímová (2019) explaining that one of the weaknesses of mobile application usage in English learning was the technical problems. Lecturer 3, 4,5 6, and 8 claimed that the internet connection limitation hindered the process of learning, but then they tried to overcome it by asking the students to use the campus Wi-Fi or to share and to ask their friends for the internet data plan. Another limitation dealing with the technical issues was the paid applications. Lecturer 7 reported that some applications could not be access completely free since some features needed to be paid or purchased. 


\section{Discussion}

Three research questions had been answered. It was discovered that the nine millennial lecturers incorporated seventeen types of online applications in their teaching. The most remarkable usage was for real-time exercise in the classroom. They also took benefits from those applications that were for establishing communication, encouraging students' self-study, improving the assessment, motivating the students and improving the teaching instructions in the classroom. As the incorporation of online application in the EFL classroom was not always run as planned, the millennial lecturers had already equipped themselves with some approaches to cope with those limitations.

\section{CONCLUSION}

This study had contributed to examine the millennial lecturers' attitudes in incorporating online applications in the EFL classroom. There were two major limitations and the millennial lecturers responded to it by giving students more information and assigning the students to do the task to solve the learning management issues and also adjusting the learning process when tool issues occur. To sum up, the researchers concluded that with their proficient competence in operating the technology, millennial lecturers were able to take advantage and overcame the possible limitations from the online application implementation in the EFL classroom with less difficulty. Further, it is suggested for future study to more specifically investigate the practice of certain online applications in the EFL classroom.

\section{ACKNOWLEDGMENTS}

We thank the family, parents, friends who have given us support both morally and materially, so that we can complete and publish our article.

\section{REFERENCES}

Azizah, D. M. (2018). The Varieties Of Homework Given By English Teachers Of Vocational Schools. Indonesian Efl Journal, 4(2), 48. Https://Doi.Org/10.25134/Ieflj.V4i2.1375

Boja, C., \& Batagan, L. (2009). Software Characteristics Of M-Learning Applications. 10th Wseas International Conference On Mathematics And Computers In Business And Economics, 88-93. Retrieved From Http://Www.Wseas.Us/ELibrary/Conferences/2009/Prague/Mcbe/Mcbe14.Pdf

Braun, V., \& Clarke, V. (2006). Using Thematic Analysis In Psychology. Qualitative Research In Psychology, 3(2), 77-101. Https://Doi.Org/10.1191/1478088706qp063oa

Bray, E., \& Iswanti, S. N. (2013). Japan - Indonesia Intercultural Exchange In A Facebook Group. The Language Teacher, (April), 29-34.

Byrne, J., \& Diem, R. (2014). Profiling Mobile English Language Learners. Jalt Call Journal, 10(1), 3-19.

Cavus, N., \& Ibrahim, D. (2008). M-Learning: An Experiment In Using Sms To Support Learning New English Language Words. British Journal Of Education Technology, 40(11), 78-91. Https://Doi.Org/Https://Doi.Org/10.1111/J.1467-8535.2007.00801.X

Chergui, O., Begdouri, A., \& Groux-Leclet, D. (2017). A Classification Of Educational Mobile Use For Learners And Teachers. International Journal Of Information And Education Technology, 7(5), 324-330. Https://Doi.Org/10.18178/Ijiet.2017.7.5.889

Chung, H.-H., Chen, S.-C., \& Kuo, M.-H. (2015). A Study Of Efl College Students' Acceptance Of Mobile Learning. Procedia - Social And Behavioral Sciences, 176, 333-339. Https://Doi.Org/10.1016/J.Sbspro.2015.01.479 
Diaz-Vera, J. E. (2012). Left To My Own Devices: Learner Autonomy And Mobile-Assisted Language Learning.

Retrieved

From

Https://Books.Google.Co.Id/Books?Hl=Id\&Lr=\&Id=T3xxhxagmcyc\&Oi=Fnd\&Pg=Pp1 $\& \mathrm{Dq}=\mathrm{Diaz}-$

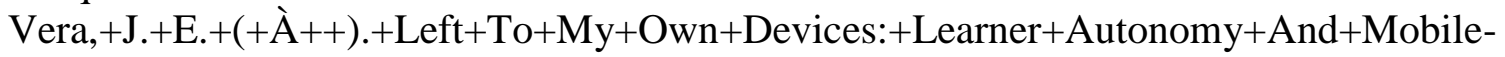
Assisted+Language+Learning.+Bingley:+Emerald.\&Ots=Chb9ovgqc2\&Sig=0gynfhtjyf5 glyrep3h3iggurwc\&Redir_Esc

El Hariry, N. A. (2015). Mobile Phones As Useful Language Learning Tools. European Scientific Journal, 11(16), 298-317. Https://Doi.Org/10.1108/09600031011093214

Eppard, J., Nasser, O., \& Reddy, P. (2016). The Next Generation Of Technology: Mobile Apps In The English Language Classroom. International Journal Of Emerging Technologies In Learning, 11(4), 21-27. Https://Doi.Org/10.3991/Ijet.V11i04.5293

Erickson, T. (2008). Plugged In: The Generation Y Guide To Thriving At Work. Retrieved From Https://Books.Google.Co.Id/Books?Id=T4_Bagaaqbaj\&Lpg=Pr13\&Ots=Kobm_Dqibp\& Dq=Erickson\%2c T. J. (2008). Plugged In\%3a The Generation Y Guide To Thriving At Work. United States\%3a Harvard Business School Press.\&Lr\&Hl=Id\&Pg=Pr13\#V=Onepage\&Q\&F=False

Gamlo, N. (2019). The Impact Of Mobile Game-Based Language Learning Apps On Efl Learners' Motivation. English Language Teaching, 12(4), 49. Https://Doi.Org/10.5539/Elt.V12n4p49

Hidayati, T., \& Endayani, T. (2019). Smartphones To Learn English: The Use Of Android Applications By Non-English Major Students In. Jurnal Ilmiah Peuradeun, 7(1), 95-112. Retrieved From Http://Journal.Scadindependent.Org/Index.Php/Jipeuradeun/Article/View/231

Hossain, M. (2018). Exploiting Smartphones And Apps For Language Learning: A Case Study With The Efl Learners In A Bangladeshi University. Review Of Public Administration And Management, 06(01), 1-5. Https://Doi.Org/10.4172/2315-7844.1000241

Jerome, A., Scales, M., Whithem, C., \& Quain, B. (2014). Millennials In The Workforce: Gen Y Workplace Strategies For The Next Century. E-Journal Of Social \& Behavioural Research In Business, 5(1), 1-12. Retrieved From Http://Www.Ejsbrb.Org/Upload/EJsbrb_Jerome,_Scales,_Whithem_Quain_5(1)_2014.Pdf

Kacetl, J., \& Klímová, B. (2019). Use Of Smartphone Applications In English Language Learning-A Challenge For Foreign Language Education. Education Sciences, 9(3), 1-9. Https://Doi.Org/10.3390/Educsci9030179

Mindog, E. (2016). Apps And Efl: A Case Study On The Use Of Smartphone Apps To Learn English By Four Japanese University Students. Jalt Call Journal, 12(1), 3-22.

Mobinizad, M. M. (2018). The Use Of Mobile Technology In Learning English Language. Theory And Practice In Language Studies, 8(11), 1456-1468. Https://Doi.Org/10.17507/Tpls.0811.10

Nowell, L. S., Norris, J. M., White, D. E., \& Moules, N. J. (2017). Thematic Analysis: Striving To Meet The Trustworthiness Criteria. International Journal Of Qualitative Methods, 16(1), 1-13. Https://Doi.Org/10.1177/1609406917733847

Phillips, C. (2019). The Most Popular And Effective English Learning Apps. Journal Of Business Administration, 93, 151-164. Retrieved From Http://Id.Nii.Ac.Jp/1060/00010543/\%0acreative

Rejeki, S., \& Azizah, A. N. (2019). Politeness Strategies Performed By Efl Learners ' With English Native Speakers In Medical Students. Humaniora, 10(March), 41-46. Https://Doi.Org/10.21512/Humaniora.V10i1.5312

Smith, J., Bekker, H., \& Cheater, F. (2011). Theoretical Versus Pragmatic Design In Qualitative Research. Nurse Researcher, 18(2), 39-51. Retrieved From 
Http://Usir.Salford.Ac.Uk/Id/Eprint/18361

Squire, K., \& Dikkers, S. (2012). Amplifications Of Learning: Use Of Mobile Media Devices Among Youth. Convergence: The International Journal Of Research Into New Media Technologies, 18(445-464).

Vaismoradi, M., Jones, J., Turunen, H., \& Snelgrove, S. (2016). Theme Development In Qualitative Content Analysis And Thematic Analysis. Journal Of Nursing Education And Practice, 6(5). Https://Doi.Org/10.5430/Jnep.V6n5p100

Yordming, R. (2017). Teachers' Perspective Towards Digital Teaching Tools In Thai Efl Classrooms. International Journal Of Languages, Literature And Linguistics, 3(2), 45-48. Https://Doi.Org/10.18178/Ij1l1.2017.3.2.108

Zhang, L. Z. (2017). College English Teaching Based On Mobile Learning. Proceedings Of The 4th International Conference On Education, Management, Arts, Economics And Social Science (Icemaess 2017). Https://Doi.Org/Https://Doi.Org/10.2991/Icemaess17.2017.125 